Research article

Open Access

\title{
The AIB1 glutamine repeat polymorphism is not associated with risk of breast cancer before age $\mathbf{4 0}$ years in Australian women
}

\author{
Karen G Montgomery ${ }^{1}$, Jiun-Horng Chang², Dorota M Gertig², Gillian S Dite², \\ Margaret R McCredie ${ }^{3}$, Graham G Giles ${ }^{4}$, Melissa C Southey ${ }^{5}$, John L Hopper ${ }^{2}$ and \\ lan G Campbell 1
}

\author{
${ }^{1}$ Cancer Genetics Laboratory, Victorian Breast Cancer Research Consortium, Peter MacCallum Cancer Centre, St. Andrews Place, East Melbourne, \\ Victoria, Australia \\ ${ }^{2}$ Centre for Genetic Epidemiology, The University of Melbourne, Carlton, Victoria, Australia \\ ${ }^{3}$ Department of Preventive and Social Medicine, University of Otago, Dunedin, New Zealand and (previously) Cancer Epidemiology Research Unit, \\ The Cancer Council of New South Wales, Sydney, New South Wales, Australia \\ ${ }^{4}$ Cancer Epidemiology Centre, The Cancer Council Victoria, Carlton, Victoria, Australia \\ ${ }^{5}$ Department of Pathology, The University of Melbourne, Parkville, Victoria, Australia
}

Corresponding author: lan G Campbell, ian.campbell@petermac.org

Received: 15 Oct 2004 Revisions requested: 12 Jan 2005 Revisions received: 25 Jan 2005 Accepted: 3 Feb 2005 Published: 4 Mar 2005

Breast Cancer Research 2005, 7:R353-R356 (DOI 10.1186/bcr1009)

This article is online at: http://breast-cancer-research.com/content/7/3/R353

(c) 2005 Montgomery et al.; licensee BioMed Central Ltd.

This is an Open Access article distributed under the terms of the Creative Commons Attribution License (http://creativecommons.org/licenses/by/ 2.0), which permits unrestricted use, distribution, and reproduction in any medium, provided the original work is properly cited.

\begin{abstract}
Introduction $A / B 1$, located at $20 \mathrm{q} 12$, is a member of the steroid hormone coactivator family. It contains a glutamine repeat (CAG/CAA) polymorphism at its carboxyl-terminal region that may alter the transcriptional activation of the receptor and affect susceptibility to breast cancer through altered sensitivity to hormones.

Methods We evaluated this repeat polymorphism in the context of early-onset disease by conducting a case-control study of 432 Australian women diagnosed with breast cancer before the age of 40 years and 393 population-based control individuals who were frequency matched for age. Genotyping was performed using a scanning laser fluorescence imager.
\end{abstract}

Results There were no differences in genotype frequencies between cases and control individuals, or between cases categorized by family history or by $B R C A 1$ and BRCA2 germline mutation status. There was no evidence that the presence of one or two alleles of 26 glutamine repeats or fewer was associated with breast cancer (odds ratio $=1.03,95 \%$ confidence interval $=0.73-1.44$ ), or that women with alleles greater than 29 repeats were at increased risk of breast cancer. Exclusion of women who carried a $B R C A 1$ or $B R C A 2$ mutation (24 cases) and non-Caucasian women (44 cases) did not alter the risk estimates or inferences. We present raw data, including that on mutation carriers, to allow pooling with other studies.

Conclusion There was no evidence that risk of breast cancer depends on AIB1 CAG/CAA polymorphism status, even if affected women carry a mutation in BRCA1 or BRCA2.

\section{Introduction}

Steroid hormones regulate the expression of proteins that are involved in breast cell proliferation and development, and coactivators that interact with steroid hormone receptors to modulate transcriptional activation have recently been described [1]. AIB1, located at $20 q 12$, is a member of the steroid hormone coactivator family that interacts with oestrogen receptor- $\alpha$, resulting in enhancement of oestrogendependent transcription [2]. AIB1 is moderately expressed in the normal mammary epithelium and is required for female reproductive function and mammary gland development [3]. It is overexpressed in $64 \%$ of breast tumours, and the $20 q 12$ region has been shown to be amplified in $5-10 \%$ of breast cancers and $7 \%$ of ovarian cancers $[2,4]$.

AIB1 contains a glutamine repeat (CAG/CAA) polymorphism at its carboxyl-terminal region. Although its functional significance is currently unknown, it may alter the transcriptional acti- 
vation of the receptor (as is the case for the androgen receptor CAG repeat polymorphism), and hence it may affect breast cancer susceptibility through altered sensitivity to hormones [5]. We evaluated this repeat polymorphism within the context of early-onset disease by conducting a case-control study of Australian women diagnosed with breast cancer before the age of 40 years and population-based control individauls $[6,7]$.

\section{Materials and methods Participants}

The Australian Breast Cancer Family Study is a populationbased, case-control family study conducted in Melbourne and Sydney $[6,8]$. For this study, cases were women aged under 40 years at diagnosis of a first primary invasive breast cancer between 1992 and 1995, and were identified through the Victoria and New South Wales cancer registries. Controls were women without breast cancer selected via the electoral rolls (registration is compulsory) between 1993 and 1999 and were frequency matched for age. Cases and controls were administered the same questionnaire on risk factors, blood samples were collected from them at the time of interview, and a detailed family history was recorded for all first-degree and second-degree relatives, with verification sought for all reports of family cancers. To date 25 of these cases have been found to carry a deleterious germline mutation in BRCA1 and 11 in $B R C A 2$ [9]. Written informed consent was obtained from all participants, and approval of the protocol was obtained from the relevant ethics committees.

\section{Genotype analysis}

PCR amplifications were performed with a fluorescent labelled forward primer (5'-GACAACAGAGGGTGGCTAT-3') and an unlabelled reverse primer (5'-AGGAGCTTGTGGCATTGTG3'). All PCRs were performed in $10 \mu$ volumes containing 10$50 \mathrm{ng}$ genomic DNA, $200 \mathrm{nmol} / \mathrm{l}$ dNTPs (Promega, Annandale, New South Wales, Australia), $25 \mathrm{ng}$ of each primer, $1 \times$ ReddyMix buffer (Abgene, Epsom, Surrey, UK) and 0.2 units of Thermoprime Plus DNA Polymerase (Abgene). PCR amplification cycle conditions involved an initial denaturation step at $94^{\circ} \mathrm{C}$ for $5 \mathrm{~min}, 40$ cycles of denaturation at $94^{\circ} \mathrm{C}$ for $15 \mathrm{~s}$, annealing at $55^{\circ} \mathrm{C}$ for $30 \mathrm{~s}$, and extension at $72^{\circ} \mathrm{C}$ for $45 \mathrm{~s}$. This was followed by a further extension step at $72^{\circ} \mathrm{C}$ for 7 $\mathrm{min}$. The alleles were then separated on sequencing gels and analyzed using a scanning laser fluorescence imager (Bio-Rad FX Molecular Imager; Bio-Rad, Hercules, CA, USA). DNA was available for $410(88 \%)$ out of 466 cases and for $441(74 \%)$ out of 600 controls, and $A / B /$ genotyping was successful for all but $17(4 \%)$ cases and $9(2 \%)$ controls.

\section{Statistical analysis}

Allele frequencies and genotypes were compared using Pearson's $\chi^{2}$ test. Odds ratios (ORs) and $95 \%$ confidence intervals (Cls) were calculated using unconditional logistic regression, adjusting for reference age, study centre, country of birth, education level, marital status, number of live births, height, current oral contraceptive use status and reported first-degree family history. Routine model diagnostics procedures and goodnessof-fit were performed to check the adequacy of the logistic regression models. All tests were performed using Stata version 8.0 (Stata Corporation, College Station, TX, USA). Power calculations were performed using StatCalc module of Epi Info version 6 (Centers for Disease Control and Prevention [CDC], Atlanta, GA, USA). All statistical tests were two-sided.

\section{Results}

For controls the allele frequencies for 26, 27, 28, 29, 30 and 31 repeats were $0.12,0.002,0.36,0.50,0.005$ and 0.002 , respectively. For cases they were $0.13,0.001,0.35,0.51$, 0.004 and 0 , respectively. Table 1 shows that there was no difference overall between breast cancer cases and controls in allele frequencies $(P=0.7)$ or genotype frequencies defined by the number of repeats $(P=0.3)$. There were no differences in the genotype distribution of cases by family history $(P=$ 0.1 ).

Table 2 shows the estimates of breast cancer risk; we chose a cutoff of 26 repeats or fewer because that had been used in a previous study [1]. There was no evidence that women with one or two alleles had increased risk of breast cancer (OR $=$ $1.03,95 \% \mathrm{Cl}=0.73-1.44$ ) or that women with alleles of greater than 29 repeats were at increased risk. Exclusion of women who carried a BRCA1 or BRCA2 mutation (24 cases) and non-Caucasian women (44 cases) did not alter risk estimates or inferences. For example, the OR for the association with one or two alleles of 26 repeats or fewer became 1.09 $(95 \% \mathrm{Cl}=0.76-1.56)$.

\section{Discussion}

In the present study of Australian women the allele frequencies and genotype distributions for the $A / B 1$ glutamine repeat (CAG/CAA) polymorphism were similar to those reported in previous studies $[1,7]$. We found no evidence that the risk of early-onset breast cancer depended on AIB1 genotype. We have presented the raw data, including that on mutation carriers, to allow pooling with other studies.

The only other study of breast cancer risk and this polymorphism in noncarriers of a $B R C A 1$ or $B R C A 2$ mutation was conducted in women aged 43-69 years [1]; it found no association. Those investigators found a weak suggestion that premenopausal women who carried two short $A I B 1$ repeats were at decreased risk, but we did not find any support for this in women under the age of 40 years.

Evidence for an increased risk in women with longer repeat lengths has been reported in $B R C A 1$ and $B R C A 2$ mutation carriers [3]. There was no indication from our data that mutation carriers, irrespective of the gene, were at increased risk if they carried longer repeat lengths, but because of the small numbers included we had little power to address this issue. 
Table 1

\begin{tabular}{|c|c|c|c|c|c|c|c|}
\hline \multirow[t]{2}{*}{ Number of repeats in AIB1 } & \multirow[t]{2}{*}{ Controls } & \multirow[t]{2}{*}{ Cases } & \multirow[t]{2}{*}{ Total } & \multicolumn{4}{|c|}{ Cases } \\
\hline & & & & $\begin{array}{l}\text { Without family } \\
\text { history }\end{array}$ & $\begin{array}{l}\text { With family } \\
\text { history }\end{array}$ & $\begin{array}{l}B R C A 1 \text { mutation } \\
\text { carriers }\end{array}$ & $\begin{array}{l}B R C A 2 \text { mutation } \\
\text { carriers }\end{array}$ \\
\hline $26 / 26$ & $5(1.2)$ & $9(2.3)$ & $14(1.7)$ & $4(1.5)$ & $5(4.3)$ & $0(0)$ & $0(0)$ \\
\hline $26 / 28$ & $39(9.0)$ & $34(8.7)$ & $73(8.9)$ & $24(8.7)$ & $10(8.6)$ & $2(14.3)$ & $0(0)$ \\
\hline $26 / 29$ & $58(13.4)$ & $52(13.2)$ & 110 (13.3) & $40(14.5)$ & $12(10.3)$ & $0(0)$ & $1(9.0)$ \\
\hline $27 / 28$ & $1(0.2)$ & $0(0)$ & $1(0.1)$ & $0(0)$ & $0(0)$ & $0(0)$ & $0(0)$ \\
\hline $27 / 29$ & $1(0.2)$ & $1(0.3)$ & $2(0.2)$ & $1(0.36)$ & $0(0)$ & $0(0)$ & $0(0)$ \\
\hline $28 / 28$ & $56(13.0)$ & $64(16.3)$ & $120(14.6)$ & $52(18.8)$ & $12(10.3)$ & $5(35.7)$ & $2(18.2)$ \\
\hline $28 / 29$ & $160(37.0)$ & $116(29.5)$ & 276 (33.5) & $81(29.4)$ & $35(29.9)$ & $3(21.4)$ & $3(27.3)$ \\
\hline $28 / 30$ & $2(0.5)$ & $1(0.3)$ & $3(0.4)$ & $1(0.34$ & $0(0)$ & $0(0)$ & $0(0)$ \\
\hline $29 / 29$ & $106(24.5)$ & $114(29.0)$ & $220(26.7)$ & $71(25.7)$ & $43(36.8)$ & $4(28.6)^{a}$ & $5(45.5)^{a}$ \\
\hline $29 / 30$ & $2(0.5)$ & $2(0.5)$ & $4(0.5)$ & $2(0.7)$ & $0(0)$ & $0(0)$ & $0(0)$ \\
\hline $29 / 31$ & $2(0.50)$ & $0(0)$ & $2(0.2)$ & $0(0)$ & $0(0)$ & $0(0)$ & $0(0)$ \\
\hline Total & 432 & 393 & 825 & 276 & 117 & 14 & 11 \\
\hline
\end{tabular}

Shown is the distribution of genotypes defined by the observed $A / B 1$ glutamine repeat alleles $(n[\%])$ in cases and controls, and in cases categorized by family history and by $B R C A 1$ and $B R C A 2$ germline mutation status. aOne case, with the 29/29 repeats $A / B 1$ genotype, had a germine mutation in $B R C A 1$ and a germline mutation in $B R C A 2$ [9].

Table 2

\begin{tabular}{|c|c|c|c|}
\hline Genotype $^{a}$ & Cases ( $n[\%])$ & Controls ( $n[\%])$ & OR $(95 \% \mathrm{Cl})^{\mathrm{b}}$ \\
\hline 0 & $298(76)$ & 330 (76) & 1.00 (reference) \\
\hline 1 & $86(22)$ & $97(23)$ & $0.97(0.68-1.38)$ \\
\hline 2 & $9(2)$ & $5(1)$ & $2.17(0.69-6.85)$ \\
\hline 1 or 2 & $95(24)$ & $102(24)$ & $1.03(0.73-1.44)$ \\
\hline
\end{tabular}

aGenotype defined as number of alleles with 26 or fewer repeats. ${ }^{b}$ Adjusted for study centre (Melbourne/Sydney), reference age (years), country of birth (Australia/other), education level (three levels), marital status (ever/never), number of live births, height (cm), current oral contraceptive use (yes/no) and affected first-degree relative (yes/no). Cl, confidence interval; OR, odds ratio.

\section{Conclusion}

We found no evidence that risk of breast cancer depends on AIB1 CAG/CAA polymorphism status, even if affected women carry a mutation in BRCA1 or BRCA2.

\section{Competing interests}

The author(s) declare that they have no competing interests.

\section{Authors' contributions}

KGM and IGC conceived the study; participated in its design, concept and coordination; and drafted the manuscript. J-HC performed the statistical analysis. DMG, JLH, GGG and MRM participated in the concept and coordination, are the chief investigators and developed ABCFS, and helped to draft the manuscript. GSD contributed to the design and management of data. MCS contributed to the design and management of laboratory processes at the GEL to enable and provide the required biospecimens for genetic analysis.

\section{References}

1. Haiman CA, Hankinson SE, Spiegelman D, Colditz GA, Willett WC, Speizer FE, Brown M, Hunter DJ: Polymorphic repeat in AlB1 does not alter breast cancer risk. Breast Cancer Res 2000, 2:378-385.

2. Anzick SL, Kononen J, Walker RL, Azorsa DO, Tanner MM, Guan XY, Sauter G, Kallioniemi OP, Trent JM, Meltzer PS: AIB1, a steroid receptor coactivator amplified in breast and ovarian cancer. Science 1997, 277:965-968.

3. Rebbeck TR, Wang Y, Kantoff PW, Krithivas K, Neuhausen SL, Godwin AK, Daly MB, Narod SA, Brunet JS, Vesprini D, et al.: Modification of BRCA1- and BRCA2-associated breast cancer 
risk by AIB1 genotype and reproductive history. Cancer Res 2001, 61:5420-5424.

4. Bautista S, Valles H, Walker RL, Anzick S, Zeillinger R, Meltzer P, Theillet $C$ : In breast cancer, amplification of the steroid receptor coactivator gene AIB1 is correlated with estrogen and progesterone receptor positivity. Clin Cancer Res 1998, 4:2925-2929.

5. Chamberlain NL, Driver ED, Miesfeld RL: The length and location of CAG trinucleotide repeats in the androgen receptor $\mathrm{N}$-terminal domain affect transactivation function. Nucleic Acids Res 1994, 22:3181-3186.

6. McCredie MR, Dite GS, Giles GG, Hopper JL: Breast cancer in Australian women under the age of 40 . Cancer Causes Control 1998, 9:189-198.

7. Kadouri L, Kote-Jarai Z, Easton DF, Hubert A, Hamoudi R, Glaser $B$, Abeliovich D, Peretz T, Eeles RA: Polyglutamine repeat length in the AIB1 gene modifies breast cancer susceptibility in BRCA1 carriers. Int J Cancer 2004, 108:399-403.

8. Hopper JL, Chenevix-Trench G, Jolley DJ, Dite GS, Jenkins MA, Venter DJ, McCredie MR, Giles GG: Design and analysis issues in a population-based, case-control-family study of the genetic epidemiology of breast cancer and the Co-operative Family Registry for Breast Cancer Studies (CFRBCS). J Natl Cancer Inst Monogr 1999, 26:95-100.

9. Dite GS, Jenkins MA, Southey MC, Hocking JS, Giles GG, McCredie MR, Venter DJ, Hopper JL: Familial risks, early-onset breast cancer, and BRCA1 and BRCA2 germline mutations. J Natl Cancer Inst 2003, 95:448-457. 